\title{
Thematic Progression in Online Algerian Newspaper Articles: Insights to Producing Coherent Texts
}

\author{
Touria Drid \\ Kasdi Merbah University, Ouargla, Algeria \\ thouriadrid@gmail.com
}

\begin{abstract}
This paper presents an analysis of the preferred thematic progression patterns used in a sample of online English versions of Algerian news articles written by Algerian journalists and appearing originally in Arabic. The purpose is to detect the recurrent patterns in this media genre. Departing from the more clause-centered models for the analysis of thematic development, the present study uses a categorization of thematic progression patterns derived from McCabe's (1999) and Daneš's (1974) models as a framework for the analysis. The corpus of the study comprises 30 online English articles that appeared in two Algerian newspapers Echorouk and Ennahar. The analysis proceeded by a T-unit segmentation of the collected articles in terms of themes and rhemes. Subsequently, determining intersentential connections as to the reiteration, alteration, or splitting of these two central constituents followed. Ultimately, patterns of sequencing were defined in the entirety of texts in the corpus. The results point toward a more frequent use of Simple Linear Progression and Constant Theme Progression. Derived Theme and Split Theme patterns are rarely used, while Split Rheme Progression does not feature in the data. Significant rates of ruptured themes are also recorded. The paper concludes by deriving useful insights as to finding ways of upgrading the writing of more coherent newspaper articles based on careful consideration of thematic progression.
\end{abstract}

Keywords: online newspaper article, theme, thematic progression, rheme

\section{Introduction}

Communication research has demonstrated that news exchange is now the most involved activity after the daily conversation. Because of the effect that news has on people in everyday life, newsmaking has become an important pursuit in the contemporary world. Johnson-Cartee (2005) argues that when the news is made, 
the flowing surge of daily events is shaped into a fresh substance for newspapers and news programmes. Using such news, these media illuminate audiences and move their intellects, or even passions, through a socially-oriented construction of reality. Given the centrality and weight of news production, the examination of news as discourse has become a rich area of inquiry in linguistics. The overall goal of such research is to comprehend the morphology of such a forceful communication medium from linguistic and critical angles. Some linguists have given special attention to news articles, the subdivisions of newspapers which say something about foregoing political, social or cultural events (Van Dijk, 1985). In discourse analysis, news articles are seen as a self-contained discourse type within the news genre. They attract readerships looking for information about daily happenings. On these grounds, the journalists producing news articles should observe the norms of writing such texts for better communicative impacts on audiences.

To construct effective news discourse, attention should be paid to the internal connectedness of the text, or coherence, among other aspects. One of the methods to achieve coherence is to consider thematic progression, that is, making a text hang together through thematic inter-sentential relations. It is argued that appropriate maneuvering of the sequential relationships which tie information encoded in themes or rhemes at sentence level with subsequent information in the rest of any text yields effective, organized and intact pieces of written discourse (Eggins, 2004; Paltridge, 2006). When composing in a foreign language, this task is found to be strenuous, even for advanced writers (Flowerdew, 2013), leading to a perceived unnaturalness in discourse. On this basis, researching thematic progression in non-native writers' news discourse may pinpoint failings in the structuring of information in media texts, which affect text coherence.

Within the bulk of research on thematic connectedness in news discourse, several studies have focused on news articles written in English and some other languages (Abed Shakeh, 2016; Al-Jayrudy, 2011; Dong, Shao \& Jia, 2016; Jing, 2015; Kadhim \& Shaker al-Shaibani, 2013; Sharndama \& Panamah, 2013; Thomson, 2005). These inquiries have considered the way news articles hang together and the way they fulfill their communicative goals. Accordingly, broad patterns of thematic development have been identified across languages within this news genre. While research on English news articles written by non-native writers from various linguistic backgrounds has been relatively abundant, the area remains understudied in the Algerian context. This scarcity of research relates in some way to the history of the Algerian press. 
A review of the Algerian press's history shows that news was initially produced in French (the colonizer's language) then in Arabic (the local language). This development has correlated with major changes that marked the history of the nation (Bousiala, 2005; Kerlil, 2005; Saif Al-Islam, 1981; Saif Al-Islam, 1982). News production in English is relatively a novelty in Algeria. It is now taking its way in the Algerian society in line with the swift advances made in every sector of life. Indeed, modern nations regardless of what languages are functional in their societies, resort to using English versions of news as a way of reaching multiplied numbers of news receivers, for the scope of news dissemination is partially relative to the audience's knowledge of the language(s) chosen. Algeria makes no exception.

Against this background, this paper aims to investigate the recurrent patterns of thematic progression employed in a corpus of online English newspaper articles written by Algerian journalists to develop their texts and to check whether these texts stand as coherent wholes. The findings generally point toward a propensity on the part of the journalists to use Simple Linear Progression and Constant Theme Progression more repeatedly. Derived Theme and Split Theme patterns are rarely used, while Split Rheme Progression does not feature in the data. Furthermore, significant rates of ruptured themes are recorded in the analyzed texts. The paper first gives a concise review of the literature on the birth and foundations of theme/rheme research, as well as the models for analyzing thematic progression. Subsequently, it explains the methodological framework of the study, with a description of the corpus and a synopsis of the analytical procedure. Finally, the paper offers a description and interpretation of the findings, based on which several implications are drawn.

\section{Literature Review}

\section{Theme and Rheme: Theoretical Framework}

To comprehend the way the system of thematic progression in news texts contributes to rendering them intact and semantically consistent, the fundamental concepts of this functional analysis have to be expounded on. Originally coined by the Prague school linguists and developed in Hallidayian systemic functional linguistics (Trask, 2007), the concepts of theme and rheme have been introduced to refer to a way of parsing a sentence which differs markedly from the traditional grammatical subject/predicate division. In essence, the theme serves as 'a point of departure' for a clause, and rheme serves as the development (Halliday and Matthiessen, 2004). According to Brown and Yule (1983), a theme is as 'a formal 
category, the left-most constituent of the sentence' (p. 126), while rheme is seen as 'everything else that follows in the sentence which consists of "what the speaker states about, or regarding, the starting point of the utterance" (p.126). McCarthy (1991) regards a theme as a framework for what is said in a clause, and he explains that the means for its realization vary.

Some linguists have attempted to link theme/rheme analysis to other discourse phenomena. Fibras (1964), for example, stresses the connection of thematization to the concept of communicative dynamism. He foregrounds the asymmetrical communicative status of themes and rhemes in a sentence. He argues that unlike themes, which convey somewhat little additional meaning to what has already been stated, rhemes possess a higher extent of communicative dynamism. The choice of topics influences information flow and shapes the overall structuring of texts. Other linguists associate the theme/rheme distinction to the notions of 'given' and 'new' information (Prince, 1979; Prince, 1981), holding that new information is expected to appear in the rheme, while given information occurs in the theme. It is shown, however, that this correlation is only limited as the two distinctions belong to different discourse systems (Flowerdew, 2013; Halliday, 1967).

Thematized units in a clause can take a wide range of syntactic forms. Indeed, there is no one-to-one connection between the traditional sentence grammatical elements, like subjects, complements or adjuncts, and themes, although, in English, themes very often concur with subjects (Crystal, 2008). Three types of themes are distinguished depending on the metafunction they carry: experiential, textual and interpersonal (Halliday \& Matthiessen, 2004; Fontaine, 2013; Paltridge, 2006; Thompson, 2014). ${ }^{1}$ The archetypal experiential theme, or the unmarked type, is the topic of the clause; that is, it coincides with the subject of the sentence. A textual theme is a structural element, such as coordinating conjunction (and, but, etc), a continuative move (yes, no, well, oh, now) or a conjunctive adverb. An interpersonal theme is usually placed before the rheme and designates the relationship between participants or the point of view supported in the clause, covering an array of meanings. It can be a modal or comment adjunct, a vocative or a finite verbal operator. In case the theme component of a sentence includes more than one element, the constituent is a case of multiple themes. Both textual and interpersonal themes are said to be marked. On the notion of markedness, Lock (1996) notes:

\footnotetext{
${ }^{1}$ In systemic functional linguistics, metafunctions realize the context of situation (Flowedew, 2013)
} 
'When any constituent other than the Subject functions as Theme, it is regarded as marked Theme [italics ours]. Such a constituent may be thought of as ... having been moved from its unmarked position to the front of the clause.' (p. 223)

Paltridge (2006) explains that marked themes stand out as unusual methods to open a clause. Linguists differ as regards the boundaries of a theme in a sentence. To Flowerdew (2013), 'Theme is that part of the sentence which includes everything up to, but not including, the verb (p.61). He argues that such a position is useful to study the development of themes in longer stretches of texts. Many studies of theme pursue this perspective. However, other accounts, such as Halliday and Matthiessen's (2004), Thompson's (2014) and McCabe's (1999) take a dissimilar position, including only that part of the sentence up to the first experiential element. That is, the subject of the clause is excluded. In the present study, the latter position is adopted.

\section{Thematic Progression}

Apart from the purely sentential account of themes and rhemes, the subject can also be approached from a discoursal angle (Brown and Yule, 1983), yielding a different representation of the issue. Crucial in this perspective is the interconnectedness of themes across sentences and their effects on texture. The notion 'thematic progression', or 'method of development' (Fries, 1995), has been initiated by the Prague school linguist Daneš (1974) to refer to the way clausal themes and rhemes in a given text relate to and derive from one another. To scrutinise TP in discourse, analysts differ as to the boundaries of the unit of text segmentation. As MacCabe (1999) demonstrates, some prefer to take the clause as an analytical entity. For other analysts, the choice is put on the orthographic sentence. Finally, Fries (1994) opts for the T-unit, or the independent conjoinable clause complex. The T-unit is defined by Hunt (1965) as 'a single clause (or independent clause) plus whatever subordinate clauses or non-clauses are attached to, or embedded within, that one main clause' (p.93).

Most works on TP refer to Daneš's (1974) classification: constant, simple linear, derived theme and Split Rheme Progression. What characterizes the Constant Progression pattern, also called Continuous Progression, is that the same themes reiterate in subsequent sentences. Flowerdew (2013) observes that this can be realized through synonymy, pronominalisation, hyponymy, meronymy, or superordinate terms. In Simple Linear Progression, a new theme originates from the rheme of the previous clause in some way. This method is also called the zigzag pattern. The pattern shows the tendency to pick up the last point in the 
preceding text to serve as the starting point for what comes next. In Derived Theme Progression, a theme stems from a preceding superordinate one, a hypertheme, which constitutes a topic for a longer text chunk. Finally, in Split Rheme Progression, also called the Multiple-Rheme pattern, the rheme of a clause involves two ideas which are worked up in consequent clauses.

More TP models have been elaborated in the literature based on Daneš's (1974) early version. Outstanding is McCabe's (1999) modified typology of TP patterns. In this framework, she specifies two general methods of development, which she calls Theme progression and Rheme progression. According to her, the first includes constant theme and split theme. Constant theme is identical to Daneš's (1974) sub-category. In her words, 'Split Theme means that a theme may contain more than one idea, and these ideas are developed in different subsequent clauses' (p.175). The second broad category, split rheme, encompasses simple linear and split rheme progressions, which are similar to Daneš's (1974) categories. Finally, text writers often happen to leave gaps in progression when they fail to link the newly thematized material to preceding themes or rhemes. Fontaine (2013) calls this a ruptured theme. She explains that this may be used for a given rhetorical effect or simply because the speaker has failed to see the addressee's needs in receiving the text. Thus, in that case, an inconsistent progression indicates a frail point in the text.

\section{Thematic Progression and Coherence}

For a text to be coherent, its content ought to be structured logically. Although coherence of texts can be approached from various perspectives, accounting for it in terms of sentential propositional connectedness yields very important insights. In this perspective, the system of thematization contributes to rendering a stretches of discourse intact through the reiterative use of the two central clausal information elements: theme and rheme. Based on the idea of given and new, every new theme in a text stretch uses the information appearing earlier either in the themes or the rhemes of the adjacent sentences as a framework for what comes subsequently. As a result, Paltridge (2006) explains, the inter-clausal process generates information flow in the text and functions as one of the resources that make it focused and unified. A uniform movement from given to new enhances text comprehension (Downing and Locke, 2006). With the proper exploitation of the grammatical tool of thematization, writers can thus make their texts consistently structured, appealing and unambiguous. In this connection, many linguists have clarified how packing appropriate information in subsequent themes of the same text can create internal ties in the text. 
Kamler and Thomson (2006), ${ }^{2}$ for instance, show how writers may highlight or conceal meanings using theme analysis. The development of information can, in fact, be strictly controlled via thematic analysis. In the following examples, what is highlighted is dissimilar. It can be seen that the selection the starting point in a clause shapes the internal structuring of texts because the foregrounded ideas, placed first, control the direction of discourse, and if not well-manipulated, 'writing seems to miss the point or wander about, or read less authoritatively than it might' (Kamler \& Thomson, 2006, p.115). Further, they add that sometimes the choice of appropriate theme provides an opportunity for the writer to shape his/her stance and make their voices heard in the text, keeping the same lexical constituents of the sentence. In this connection, they illustrate how (in academic texts) in a stretch of text, the starting points of sentences, when focused only on what others do or say, yield only descriptive accounts of reality, excluding any argumentative or critical stance on the part of the author. However, when writers supply earlier in the clause some hints at their point of views regarding what is being reviewed, their claims would be clear as regards what they are assessing. Therefore, it seems important to pack the right content in initial position, taking into consideration what has been said earlier in the text, to produce more focused writing which suits the communicative goal of the text and its genre.

In a more theoretical account on thematic progression and its effect on text intactness, Eggins (2004) expatiates on the way the various patterns of thematic progression create connections/ disconnections in the text. In the case of constant progression, the reiteration of elements, as it is the case of lexical repetition, creates cohesion between the sections of the same text. What is more, putting the same participant (even if it appears in a nominalized or a pronominalized form) in a prominent position helps in keeping a strong topical focus. However, maintaining the same theme has some negative impact on text attractiveness, and, more importantly, it indicates that the discussion does not have a clear point since the unfamiliar content is rhematized, that is, given secondary prominence. In Eggins' (2004) words:

'If Theme is our point of departure, constancy of Theme would mean we are always leaving from the same spot, and that the 'new' information introduced in the Rhemes would not be being followed up.' (p. 224)

In the case of simple linear progression, Thematic shifting (either drawing on preceding rhematized information or on something outside the text) gives the text a

\footnotetext{
2 Kamler and Thomson's (2006) whole discussion appears in the context of dissertation writing.
} 
sense of increasing development; in other words, the text content seems to move forward. In the case of Split rheme (multiple-rheme) progression, an 'underlying organizing principle' for the overall text is created via multiple pieces of information introduced in the rheme of the first clause of the text, which are then thematized in subsequent clauses. Finally, hyperthemes (topic sentences) and even macrothemes (those signposts or headings which operate on larger pieces of discourse) in derived theme progression pattern, are said to guide readers to know about what will be said later in the text. For Kamler and Thomson (2006), these have a predictive power and are efficient in creating anticipations about the way a text will progress because they foreground chief information by making it the point of departure. Given this picture, the act of controlling the direction of information in the text is put at the disposal of text writers. In fact, through the vast number of grammatical options it offers for the construction of themes, language permits writers to choose the ones that correspond to their intentions.

Although the responsibility of selecting patterns belongs to writers, it is important to note that sometimes thematic progression is governed to a great extent by the register (spoken or written) and the genre (expositions, narratives, descriptions, etc). In this connection, Eggins (2004) shows that in spoken language, which is deficient in planning, theme reiteration is more dominant, while generally in written texts, the zig-zag and the multiple theme patterns are more recurrent. Nominalization is a further tool characterizing writing in general. Flowerdew (2013) pinpoints some thematic features of some registers and genres. In conversation, dominance of pronouns ( $I$, we, you, etc) as themes and a frequent ellipsis of pronouns are salient traits. In descriptive texts, the use of simple linear progression (with rhemes becoming themes in subsequent clauses) is very noticeable. In biographies and narratives, constant progression serves the text content and perspective very well focusing on one person. In news articles, there is more variety. In instruction manuals, imperative theme reiteration is predominant. In some types of reports, marked themes with temporal and spatial adjuncts are employed to organize texts. Finally, in guidebook genres, spacial adjuncts used as themes are very appropriate. Flowerdew concludes by showing that with more proficiency, writers can vary the patterns of their texts within the constraints of the register or genre they compose in. Against this background, it should be stressed that text writers, equipped with a good knowledge of the communicative features of every discourse type, ought to employ the grammatical tool of thematic progression efficiently to make their texts achieve their intended goals. 


\section{Learning Thematic Progression}

It has been shown that thematization is of importance to construct coherent, naturally flowing discourse. For experienced native speakers, it is effortlessly and reflexively manipulated to orient the receiver and make special foci in a text (Paltridge, 2006). However, Flowerdew (2013) reports some research findings which indicate that good manipulation of TP increases steadily over time for L1 users and that it is achieved only at relatively advanced levels of learning. Thus, it is expected to pose more difficulties for second language (L2) learners. Thus learning about thematization is pertinent to L2 language teaching in several ways. In the first place, it ascertains better manipulation of theme development and text hub. Further, through awareness of how themes are presented and developed in texts, L2 students may generate more complex and coherent discourse and may be assisted in maneuvering style for a more authentic writing. At last, underscoring cross-linguistic dissimilarities in thematization strategies can be exploited to enhance naturalness in non-native writers' texts in comparison to their native counterparts.

On these grounds, some discourse analysts call for using special language teaching materials which are text-oriented rather than sentence-oriented (Thornbury, 2005). The outcomes of the latter have proved to yield learner discourse which is grammatically impoverished and lacking in naturalness and sense of connectedness. Relating this to teaching the kernels of thematization, Jones and Lock (2011) urge language teachers to exploit the diverse kinds of prominence in different parts of the clause to enable learners to create inter-sentential links. In the same vein, McCarthy (1991) suggests that second language learners' attention ought to be drawn to thematization issues, among other textual tools, for a more effective communication in real-world situations. He stresses the need for foregrounding certain elements similar to what is found in L1 users' ordinary discourse.

\section{Methodology}

\section{Corpus}

The compiled corpus consists of 30 news articles appearing in the English online versions of two widely circulating Algerian newspapers, namely, Echorouk and Ennahar. Fifteen online English versions of articles published in each of these newspapers in June and July 2016 have been collected. Only the articles on Algerian national news were selected (See Appendix A and Appendix B). 


\section{Procedure}

The analysis was undertaken in three stages: T-unit segmentation, identification of themes and rhemes, and analysis of theme/rheme relations.

- Segmentation: The collected articles were numerically coded and segmented in terms of T-units. The T-units were tabulated for ease of analysis.

- Identification of themes and rhemes: At the level of each T-unit, themes and rhemes were identified. Theme is that constituent of the sentence which consists of everything positioned before the verb, and rheme is what follows. Analysis of both marked and unmarked themes follows Thompson's (2004) suggestions as to what constitutes a theme in the various sentence constructions. In cases where the two alternative analyses are offered, the option which is more discourse-oriented is chosen.

- Analysis of theme/rheme relations: In this stage of the analysis, TP patterns were identified in every text. That is, connections as to the reiteration, alteration or splitting of themes and rhemes in the T-units of every text were described following a categorization of TP patterns derived from McCabe's (1999) and Daneš's (1974) models. This covers five types of progression: (1) Constant Progression, (2) Split Theme Progression, (3) Simple Linear Progression, (4) Split Rheme Progression, and (5) Derived Theme Progression. Ultimately, patterns of sequencing were defined in the entirety of texts in the corpus.

- Analysis of ruptures: In cases where the sources of the theme could not be attributed to the previous text, the situation is described as a ruptured theme. The structures of themes causing ruptures were fully depicted to determine the writers' stylistic tendencies.

- Analysis of anomalies: Anomalous theme or rheme constructions were signaled.

\section{Results}

\section{General Results}

The analysis of the data yielded the general results presented in Table 1. On the whole, the findings demonstrate that the predominant TP pattern in the totality of examined articles in both newspapers is the Simple Linear Progression (40.07 \%). 
Next in frequency comes the Constant Theme Progression (38.91\%). The news articles include less significant occurrences of Derived Theme Progression and Split Theme Progression patterns with percentages of $3.11 \%$ and $0.77 \%$ respectively, while Split Rheme Progression has no occurrence. More importantly, ruptured progression appears in $17.12 \%$ of the totality of recorded patterns at Tunit boundaries.

Table 1. Frequency of Thematic Progression Patterns

\begin{tabular}{|c|c|c|c|c|c|c|}
\hline & \multicolumn{2}{|c|}{ Ennahar } & \multicolumn{2}{|c|}{ Echorouk } & \multicolumn{2}{|c|}{ Total } \\
\hline & $\mathbf{N}^{\circ}$ & $\%$ & $\mathbf{N}^{\circ}$ & $\%$ & $\mathbf{N}^{\circ}$ & $\%$ \\
\hline Constant Theme Progression & 33 & 35.48 & 67 & 40.85 & 100 & 38.91 \\
\hline Split Theme Progression & 01 & 01.07 & 01 & 0.6 & 02 & 0.77 \\
\hline Simple Linear Progression & 35 & 37.63 & 68 & 41.46 & 103 & 40.07 \\
\hline Split Rheme Progression & 00 & 0.00 & 00 & 0.00 & 00 & 0.00 \\
\hline Derived Theme Progression & 01 & 01.07 & 07 & 04.26 & 08 & 03.11 \\
\hline Ruptured Theme & 23 & 24.73 & 21 & 12.80 & 44 & 17.12 \\
\hline Total & 93 & 100 & 164 & 100 & 257 & 100 \\
\hline
\end{tabular}

It is noticed that the rates for each pattern diverge only imperceptibly in both newspapers, except for ruptured progression, where Ennahar articles have more ruptures than those of Echorouk.

\section{Discussion}

A close examination of the data provides ample evidence on how the journalists manage information prominence through theme/rheme connections to create internal textual links.

\section{Simple Linear Progression}

As seen in Table 1, the journalists have the tendency to employ the pattern of Simple Linear Progression, which is the most basic or elementary according to Daneš (1974), more than other patterns. This form of development entails that the 
writers utilize rhematized information as an opening for subsequent T-units, creating digression. The following extracts illustrate this recurrent practice (The symbol | shows T-unit boundaries and underlining indicates the theme):

[1] Ambassador Bernard EMIE, High Representative of the French Republic in Algeria, handed over on June 21, to Mr. Abdelmajid Chikhi, director of the National Archives of Algeria, twenty-two volumes of French diplomatic documents copies covering the period from 1954 to 1962.| These copies put into perspective the events that occurred during the war of Algeria and relate to developments in the foreign policy of France at that time, I we read in the communiqué. I $\underline{\text { This }}$ is part of the peaceful and trusting dialogue engaged with Algeria on the issue of Archives; a dialogue initiated following the state visit of French President François Hollande in Algeria in December 2012. (5 / Ennahar)

[2] Executive Director of Italy's Eni Claudio Descalzi has paid a secret visit to Algeria for the fourth time. I Public authorities did not reveal details about it although a meeting was held between the Italian official, the Algerian energy minister Noureddine Bouterfa and Sonatrach's CEO Amine Maazouzi. | Contracts were signed in favour of Eni. | Eni said in a release that | the Algerian energy minister Nourredine Bouterfa and Sonatrach's CEO met on June 21st with Eni's Executive Director Claudio Descalzi. | Similar meetings were held in January 2015, November 2015 and April 2016 respectively. I According to the same document, Maazouzi and Descalzi signed a contract to extend production licences in ROD field. (4 / Echorouk)

In these illustrative passages, a number of new themes in the text are extracted from that part of preceding T-units where new information is supplied. According to Alonso \& McCabe, (2000), this inclination reflects an attempt to create a dynamic text, a typical feature of explanations and exposition which permits writers to smoothly append new ideas to given ones. Alekseyenko (2013) clarifies that the choice of linear TP is related to the disproportionate shared knowledge between writers and readers, as is the case of news reporting. This is believed to restrain the array of options available for the selection of new points of departure. Thus, writers resort to previous rhemes, which become shared knowledge. It is observed in these passages, however, that the zig-zag progression does not always occur between adjacent T-units. In some of the instances of this pattern, the distance between a new theme and the rheme to which it is relevant extends over more than one T-unit. The cases in which this is done essentially derive the new 
themes either from rhemes in the article's title, the rheme of the opening sentence or from some other remote rheme in the body of the text.

\section{Constant Theme Progression}

The Constant Theme Progression pattern comes next in frequency. In this kind of development, the theme of preceding T-units is maintained as a fronted idea for the upcoming units, creating a form of continuity in the discussion of the same core content. Such a development is illustrated in the passages below:

[3] ALGIERS - a prototype of the first intelligent solar house created by a $100 \%$ Algerian research teams, under the Renewable Energy Development Center (CDER), was inaugurated on Tuesday at the headquarters of the solar equipment Development Unit (UDES) of Bou Ismail (Tipasa) in Algiers. $\mid$ This is an intelligent solar house with low energy consumption, fueled as its name indicates with solar electricity, for water treatment, operation of refrigeration equipment and air conditioning and solar heating. I This smart house and friend of nature was inaugurated on the sidelines of a tribute organized by the CDER, on the occasion of the celebration of the summer solstice, 2016 (corresponding to the longest day of the year). | "This project of ecological house is the culmination of a partnership between four (4) specialized research teams in the fields of solar energy and the environment, "|(3/ Ennahar)

[4] The Ambassador told the Senate that the imams are selected following a national competition exam |and they should have a degree. | "They take intensive courses in French language before they come to France." | Bendjamaa said | the Paris Mosque is Algerian as Algeria allocates an annual budget for it estimated at about 2 million euros. I Imams cost the government 300,000 euros per month and benefit from social security. I The Ambassador also said| mosques have nothing to do with jihadists. | (14/ Echorouk)

As seen in the extracts, writers employ a variety of reiteration methods to keep the same themes, such as lexical repetition, prenominalisation, meronymy and superordinates. Similar to Simple Linear Progression instances, invariable themes very often do not appear in contiguous T-units, creating a gap in Constant Progression. This is recorded in $29 \%$ of the totality of constant theme progression tokens, indicating that writers do not rely heavily on reiteration but make interruptions where other patterns are employed instead. Text [4] exemplifies how the journalist alternates three themes (ambassador, mosque and imams) to develop the text. 


\section{Derived Theme Progression}

Derived Theme Progression is recorded in only $3.11 \%$ of cases. In this TP pattern, writers use one overriding hypertheme and derive subsequent ones from it. The hypertheme constitutes a topic for the text. The news articles under examination contained scarce occurrences of such a development. In the following extract, the author uses several themes which all derive from one preceding theme (small cars which were the most sold in Algeria), adding a high degree of unity and engendering a smooth flow of information:

[5] Even the price of small cars which were the most sold in Algeria went up to more than 1,000,000 DZ. |Sovac group sells Skoda Fabia at 3,200,000 DZ while it was at 1,100,000 DZ in 2014. I Volkswagen Polo is now at 2,400,000 DZ compared to 1,500,000 DZ in 2014.| The price of Ibiza increased to 2,500,000 DZ while it was sold at 1,300,000 DZ. I (1 / Echorouk).

\section{Split Theme Progression}

The lowest rates of TP patterns are those of Split Theme Progression with very scarce occurrences. In this kind of development, the new themes divide a previous theme into parts. These are then separately worked up as news themes in ensuing T-units. The following examples illustrate these less used patterns in the corpus:

[6] Duplication and modernization of a section of $177 \mathrm{~km}$ of railway connecting Oued Kebir, Tebesa and Djbel Onk, are works to be covered on this project that needs 48 months of realization, I the source revealed, adding that By 2020, the East mining railway will serve to transport nearly 26 million tons of phosphate ore and derivatives, and iron ore. | The railway modernization will be conducted in parallel to the realization of other investments in partnerships that Algeria has concluded recently for greater exploitation of phosphate deposits in this region of the country. I (8/ Ennahar)

[7] Some among economic experts believe the Algerian government by adopting a new economic model had to make changes at the head of sensitive economic sectors, such as the portfolios of energy and finance, while others surmise that the latest reports of the IMF and the World Bank about Algeria's socio-economic juncture have induced such changes.| Independent economic expert Abderrahmane Mebtoul, said to this effect that $\mid$ three assessment international reports released last week coupled with the conclusions of the last tripartite meeting were behind the recent small- 
scale ministerial reshuffle which affected mainly the hydrocarbons sector and the financial resources department. | (11/ Echorouk)

\section{Split Rheme Progression}

The last pattern, Derived Theme Progression, does not feature in the data in both newspapers. This is reflective of the writers' tendency not to be analytical of rhematized information. If rhemes are employed as points of departure, as appears in the frequent use of Simple Linear Progression, this would simply serve linearity of information without any attempt to elaborate it in the rest of the text.

\section{Ruptured Themes}

Examination of TP patterns in the corpus signals the presence of excessive ruptured themes in both newspapers (Table 1), which are realized in various structures. Ruptured Progression can be an indicator of failures to create texture or simply a rhetorical tendency employed in some registers and genres to achieve some communicative goals. In the corpus, ruptured themes appear in 7 forms, as demonstrated in Table 2.

Table 2. Ruptured Themes

\begin{tabular}{lcr}
\hline Type & Frequency & Percentage \\
\hline Verbal process & 15 & $34.09 \%$ \\
New subject & 13 & $29.54 \%$ \\
Adjunct & 8 & $18.18 \%$ \\
It (anticipatory) & 4 & $9.09 \%$ \\
Multiple theme & 2 & $4.54 \%$ \\
existential 'there' & 1 & $2.27 \%$ \\
Dependent clause & 1 & $2.27 \%$ \\
Total & 44 & $100 \%$ \\
\hline
\end{tabular}

As seen in the table, verbal processes appear in $34.09 \%$ of ruptured themes, predominantly in Ennahar newspaper. They are used initially in the reporting clause of a complex sentence. Drawing on Thomson's (2014) analysis of clause complexes, the reporting clause is considered a separate T-unit. In this thematic structure, a main verb is inverted with the subject in the clause. The process expressed in the verb is thus thematized, while the subject takes rheme position. Thus, it receives further emphasis and additional communicative effect. This is often called quotative inversion (Alonso, 2007). In grammars of present-day English, this sort of inversion is considered a typical feature of journalistic writing 
(Quirk et al., 1985). Thus, it is dubbed journalistic style inversion (Schmidt, 1980). The following extracts show how this features in the data:

[8] Two shelters for terrorists in Batna and ten mines in Tizi Ouzou have been destroyed by detachments of the People's National Army, I said Thursday the Ministry of National Defence in a statement. | "As part of the fight against terrorism, Army detachments destroyed, on 22 June 2016, two shelters for terrorists in Batna, 5th Military Region and 10 mines in Tizi Ouzou, 1st Military Region," | said the statement. |As part of the fight against organized crime, "units of the border guards seized $760 \mathrm{~kg}$ of cannabis resin in Tlemcen, 2nd Military Region," | added the statement. (1 / Ennahar)

[9] CEO of CPA bank Omar Boudiab Wednesday said | electronic payment operation will be officially launched at the bank starting from July if the Bank of Algeria approves it. | "systems will be set up at banking agencies starting from today [Wednesday] to enable Air Algerie's clients to buy tickets electronically. |CPA wants to promote electronic payment operation. | This would reduce cash transactions. I The electronic operation is safe," said Boudiab. (5/ Echorouk)

In these passages, the writers put greater focus on the subjects (Ministry of National defence, statement, Boudiab) and consider the quotative verbs (said, added) as given information. A further point is that all instances of quotative inversion occur in final position, while it is typical in English news reporting to find it in other placements. All in all, this form of rupture shows a rhetorical tendency in news reporting genre rather than lacunae in manipulating coherence.

Interestingly, there is evidence that newly introduced subjects come next in frequency in ruptured themes $(29.54 \%)$. In this case, some themes in the new Tunits of the text do not relate to the previous ones, creating gaps in the discussion.

[10] These copies put into perspective the events that occurred during the war of Algeria and relate to developments in the foreign policy of France at

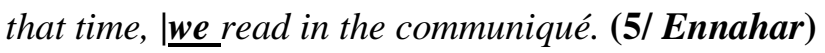

[11] Algeria and the United States are currently working to renew the cooperation agreement on science and technology, notably for scholarships, | Minister of Higher Education and Scientific Research Tahar Hadjar said Sunday in Algiers, according to APS. (13/ Ennahar)

[12] Executive Director of Italy's Eni Claudio Descalzi has paid a secret visit to Algeria for the fourth time | Public authorities did not reveal details 
about it although a meeting was held between the Italian official, the Algerian energy minister Noureddine Bouterfa and Sonatrach's CEO Amine Maazouzi.| Contracts were signed in favour of Eni. (4/ Echorouk)

In this kind of ruptures, the writers fail in linking newly introduced material to any of the already introduced information in the previous T-units. The theme (we) in extract [10] refers to an external agent not appearing in the discussion. Similarly, the theme (Minister of Higher Education and Scientific Research Tahar Hadjar) in [11] does not seem to be related to the preceding components. The writer could, for example, have modified the word (scholarships) with the expression (research scholarships) to create some kind of linearity to the previous rheme. Readers may find it difficult to establish this connection. Finally, in [12] the theme (public authorities) is completely detached from the discussion. The writer might have assumed that the reader knows that the intended authorities are identified in the Algerian context. A simple adjustment (Algerian public authorities) could have established a better flow of information. This case represents a real rupture in the flow of information.

The third type of ruptured theme, which figures largely in Echorouk articles, appears in adjunct constructions, representing $18.18 \%$ of ruptures. These are realized as an adverbial (word or phrase) or prepositional phrase (Halliday \& Matthiessen, 2004). This type of theme, according to Flowerdew (2013), designates a shift in topic, place or time. The use of adjuncts as points of departure is illustrated in extracts [13] and [14] below:

[13] Moreover, an Army detachment intercepted, Tuesday morning in El Oued, 4th Military Region, " a drug trafficker and seized a tank truck loaded with $100 \mathrm{~kg}$ of cannabis resin, while another Army detachment arrested a smuggler aboard a truck loaded with 10,795 units of different beverages, " | added the statement. I In Bordj Badji Mokhtar, 6th Military Region, another detachment "arrested five smugglers and seized an all-terrain vehicle and a quantity of spare parts," I said the Ministry's statement. (9 I Ennahar)

[14] Thousands of people who benefited from ENSEJ loans are panicked and fearful as courts asked them to pay due money as deadlines are expired. I Many of them found themselves between two choices: either to pay the money or go to jail. | According to lawyer Hassan Ibrahimi, those loans are not "political" but commercial as loans are offered by banks which can file a lawsuit if due money is not paid. (15/ Echorouk) 
In text [13] the writer clearly produces a text deficient in coherence by announcing in the title that the discussion is about three shelters for terrorists being destroyed in the region of Boumerdes, Algeria. In the ruptured theme, however, a totally new location appears in the discussion through the use of the phrase "In Bordj Badji Mokhtar, 6th Military Region". The writer fails in making the thematic development unbroken, affecting the text's coherence and focus. The rupture is not linked to the use of the adjunctive construction per se but to weak title formulation. In extract [14] as well, the use of the adjunctive construction (According to lawyer Hassan Ibrahimi), despite being unconnected to the preceding context, seems to raise the news article's credibility through the identification of the source of one of the statements reported as part of the event.

An additional type of rupture results from the use of anticipatory it. This tendency appears in $9.09 \%$ of the cases of ruptured theme. These are instances of extraposition. For Quirk et al. (1985), when this happens, a postponed element is replaced by a substitute form. In the reported cases, a clausal subject (finite or nonfinite) is shifted to the end of the sentence and its typical subject position is filled by the anticipatory pronoun it. Greenbaum (1996) explains that this postponement produces a more balanced sentence, in which the part preceding the verb is shorter than the part following it. It is argued that in English grammar, this is a rhetorical device which serves the informational and stylistic principle of 'end-weight', that is 'shortest first, longest last'. Extraposed constructions would appear less awkward. The outcomes of extraposition on the textual level appear in packaging information in a mode that facilitates its processing. When new items are introduced in the text, they need to be fully described and detailed more than known elements; hence, they are positioned last (Downing \& Locke, 2006). The following extracts [15] and [16] illustrate this thematic organization:

[15] In a statement to the press after the signing of a cooperation agreement between the sector and the High Commission for Amazigh (HCA), Mr. Zitouni said | "It was impossible to meet the demand of the pied noirs with financial compensation for the property they owned during the French occupation of Algeria." (2/ Ennahar)

[16] It also said | partnership between Eni and Sonatrach will lead to the establishment of a huge program to boost productive operations which will use very sophisticated technologies.| It is not yet clear why the Algerian government keeps silent over visits paid by Eni's officials. (4/ Echorouk)

It appears in these extracts that postponed subjects signal that the writers purposefully place more emphasis on the information supplied in the rheme 
through the use of it. Thematized it is semantically empty, and it could not be linked to the preceding themes or rhemes. Thus, formally, this represents a ruptured theme. Informationally, however, the strategy is a rhetorical device that creates more focus in the text as it maximizes the cognitive processing of information flow.

In addition to the previously discussed forms of thematic breaks, the analyzed texts in the data display slightly infrequent instances of other sorts of ruptured themes. These cover multiple themes, existential there and dependent clause constructions $(4.54 \%+2.27 \%+2.27 \%=9.08 \%)$. The two instances of multiple themes contain a textual element in the form of conjunctions (and, yet). The existential construction involves the use of existential there as theme serving as a 'representation element' (Downing \& Locke, 2006), while the dependent clause construction starts with a dependent clause as theme functioning as a locative. The following excerpts demonstrate these cases respectively:

[17] "In my capacity of Algeria's Ambassador to Paris, I have a special mission as I represent a free and proud country. I Partnership between us reached exceptional levels thanks to our both Presidents' will.| $\underline{\text { Yet }}$, it is also easy to look back to see how the two last centuries were spent amid conflicts.| (14/ Echorouk)

[18] "Algerian-French relations can be good and can be bad |but they will never be ridiculous and absurd,"' he added. | The Ambassador also said| there is one Islam only.| "Due to the present financial situation, Algeria can almost find money to cover expenses for imams in France”. (14/ Echorouk)

[19] Saoura-Ciment company, a GICA subsidiary, has begun work on a new cement plant, | cemnet.com website reported on Wednesday. | The industrial projects in Bechar are part of the new strategy of national industry development,| said Tuesday Minister of Industry and Mines Abdessalem Bouchouareb. Situated $965 \mathrm{~km}$ south of Algiers, the greenfield Bechar cement plant will cost DZD34bn to build and will have a cement capacity OF 1Mta, I the source added. (6/ Ennahar)

Added to the reported patterns of thematic progression and the various forms of thematic ruptures, the data contained one instance of anomalous forms of sentence elements. The extract in [20] is a case of an anomalous rheme:

[20] At the last visit of the President of the Tunisian Renaissance to Algeria and his prolonged meeting with President Bouteflika, which was devoted in its large part to the situation in Libya, they agreed that the 
"Sheikh" will pay mediation with the Libyan parties that refused access of Fiaz Seradj and Presidential Council, which led him to the capital to take over his duties, pursuant to the agreement that is reached among the opponents of the Libyan crisis and the international community, which is represented by the United Nations, in light of the crisis in Libya and the political division in the country, which resulted in the emergence of two conflicting governments, between the National Salvation Government, that is based in Tripoli, and which do not have an international legitimacy, despite its dominance by $75 \%$ of the country's territory, and the interim government in the east of the country, which was given international legitimacy, despite its inability to carry out its powers, to the extent that its President Abdellah al-Thani was prevented by armed groups from leaving his office. I Ghannouchi moved his belonging to the Muslim Brotherhood, to secure the entry of Faiz Serradj who already won.| (12/ Echorouk)

This excerpt shows the tendency of its writer to employ an extremely complex rheme (the use of 10 subordinate clauses in the same sentence), which renders the content incomprehensible because of excessive packing of information.

\section{Summary}

Generally, the results of analyzing thematic progression in English online newspaper articles show that most importantly, the writers tend to be digressive through the use of the Simple Linear Progression (or zig-zag) pattern $(40.07 \%$ ). The outcome is textual dynamism. That is to say, the text's content appears to progress, giving a sense of increasing development. The writers advance new knowledge in the rhemes then use it as shared knowledge in the construction of the following units, hence, fulfilling the core function of news reporting, that is, presenting raw information about recent events. Next in prominence is the use of the Constant Theme Progression pattern (38.91\%), using a range of reiteration methods_lexical repetition, pronominalisation, meronymy and superordinates_and frequently interrupted with other patterns. This kind of development is based on the stability of discussing unchanged core content resulting in more cohesive and topically focused texts. On the other hand, it obscures the point of the news article because the new content is given a minor status, for it is rhematised.

Derived Theme Progression and Split Theme Progression were very infrequently used by the journalists ( $3.11 \%$ and $0.77 \%$ respectively), while no instance of the Split Rheme pattern was recorded $(0.00 \%)$. This demonstrates the tendency not to be analytical of previously stated information. In the case of Derived Theme 
Progression, writers could have exploited this development to orient readers to what will be said later in the text. By foregrounding chief information as a point of departure, derived themes can help readers look forward to upcoming content, and hence they can guide information flow. In the same way, the writers could have utilized Split Rheme Progression to construct a main organizing principle for the entire texts through many pieces of information packed in the rheme of the initial clause of the text, which are thematized, i.e. set as points of departure, in the following units.

The analysis of the data revealed also that the newspaper articles' writers use some forms of ruptures $(17.12 \%)$ and in very scarce instances produce anomalous complex rheme structures. Some of the recorded ruptures represent certain rhetorical features, such as verbal processes (journalistic style inversion); shifts in topic, place or time; and end-weight. Other recorded ruptures, as is the case of introducing totally new thematized material or using unrelated locative adjunctive construction, create genuine gaps in the discussion which breach its internal connectedness. Finally, inconsistency in constructing rhemes (the excessive use of subordination) is a feature which reflects the writers' lack of awareness of the boundaries of complexity in English sentence construction.

\section{Conclusion}

This paper reports a study which examines, from a discourse analysis perspective, the Algerian journalists' English news articles in two Algerian online newspapers Ennahar and Echorouk. Focus is placed on the system of thematic progression, which may render texts more coherent if used properly. This approach to coherence highlights the sentential propositional connectedness as a way to establish intersentential relationships. The latter is achieved by structuring the text into information blocks through themes and rhemes. Examining news discourse from this angle helps in identifying failings in the structuring of information in such texts. The results of the study indicate that, by and large, the journalists use mostly Simple Linear Progression and Constant Theme Progression. As a result, the analyzed news articles show the journalists' general inclination either to digress, producing dynamic texts or to repeat the same propositional content in themes, leading to more cohesiveness and focus in articles. In either case, the texts seem to be intact, but they differ in the extent of information flow. Less prevalent is the use of other patterns of thematic progression, but also frequent is the use of ruptures. Based on the results, the study provides empirical evidence on some salient 
discourse features and patterns that Algerian journalists use to develop news articles thematically in English.

Given such findings, one can conclude that a good exploitation of thematic progression in writing the news articles under scrutiny is only relatively achieved, added to some observed inconsistencies. It should be stressed that the effective use/misuse of thematization patterns does affect the way a text hangs together. It is only through a correct manipulation of thematic shifts that writers can provide a sense of direction in the text and can orient their audiences to their point of discussion. Proficient writers strategically control the flow of their texts using natural-sounding shifts. It is suggested that writers' attention ought to be drawn to such discourse features, among other textual tools, for a more effective communication. In teaching English journalistic writing to non-native speakers of English, emphasis should be put on the various patterns of progression and their rhetorical effects. We ought to raise their awareness of how themes are presented and developed in texts so that they can generate more complex and coherent discourse and may be assisted in maneuvering style for a better media effect. Cross-linguistic dissimilarities in thematization strategies can be exploited to enhance naturalness in non-native writers' texts in comparison to their native counterparts. It should be remembered that texts with inadequately manipulated thematization leave the impression of 'a sort of flat landscape in which each bit of information is doled out without any overall sense of direction or organization, and with equal weight given to all the elements of the message' (McCarthy, 1991, p.53). We believe that this paper, which approaches media texts from a purely linguistic angle, is useful for journalists with an interest in writing more forceful English news articles. Such research might enlighten practitioners and professionals and might assist in empowering the mechanisms of news production in English in the Algerian context in an era where online news dissemination has become compelling. This urgency increases more than ever when the language employed is international and has the potential of reaching very wide audiences.

\section{References}

Abed Shakeh, N. (2016) Thematic progression in the rhetorical sections of an online Iraqi English newspaper. International Journal of Foreign Language Teaching and Research, 4(13), 59-68.

Alekseyenko, N.V. (2013) A corpus-based Study of Theme and Thematic Progression in English and Russian Non-translated Texts and in Russian Translated Texts. (Doctoral thesis). Kent State University, Kent, USA.

Al-Jayrudy, L. (2011) Ideological Representations in English and Arabic News Reports: A Thematic Structure Analysis. (Doctoral thesis). Heriot-Watt University, Edinburgh, UK. 
Alonso, I. A. and McCabe, A. M. (2000) Theme, transitivity and cognitive representation in Spanish and English written texts. Revista Canaria de Estudios Ingleses, 40, 2000, 77-94. Available from: https://www.researchgate.net/publication/28057179_Theme _transitivity_and_cognitive_representation_in_Spanish_and_English_written_texts. [Accessed 8th December 2017].

Alonso, J. C. P. (2007) Inversion in Written and Spoken Contemporary English. (Doctoral thesis). University of Santiago de Compostela, Santiago de Compostela, Spain.

Bousiala, Z. (2005) Essahafa El-maqtuba wa dimocratia fi el-jaza'ir [Written press and democracy in Algeria]. (Unpublished Masters' dissertation). University of Algiers, Agiers, Algeria.

Brown, G. and Yule, G. (1983) Discourse Analysis. Cambridge: Cambridge University Press.

Crystal, D. (2008) A Dictionary of Linguistics and Phonetics (6th ed.). Oxford: Blackwell.

Daneš, F. (1974) Functional sentence perspective and the organization of the text. In: F. Daneš (Ed.), Papers on functional sentence perspective (pp. 106-128). The Hague: Mouton.

Dong, T., Shao, P. and Jia, J. (2016) The study on thematic progression patterns of English news. English Linguistics Research, 5(3), 15-20.

Downing, A. and Locke, P. (2006) English Grammar: A University Course (2nd ed.). Abingdon and New York: Routledge.

Eggins, S. (2004) An Introduction to Systemic Functional Linguistics. London: Continuum.

Firbas, J. (1964) On defining the theme in functional sentence analysis. Traveaux Linguistiques de Prague, 1, 267-280.

Flowerdew, J. (2013) Discourse in English Language Education. London: Routledge.

Fontaine, L. (2013) Analyzing English Grammar: A Systemic Functional Introduction. Cambridge: Cambridge University Press.

Fries, P. H, (1994). Theme, method of development, and texts. World Englishes, 21(2), 317-359.

Fries, P. H. (1995) A personal view of theme. In: Ghadessy, M. (Ed.) Thematic Development in English Texts (pp. 1-19). London: Pinter.

Greenbaum, S. (1996) The Oxford English Grammar. Oxford: Oxford University Press.

Halliday, M. A. K. and Matthiessen, C. (2004) An Introduction to Functional Grammar (3 ${ }^{\text {rd }}$ ed.). London: Edward Arnold.

Halliday, M.A.K. (1967) Notes on transitivity and theme in English: Part 2. Journal of Linguistics, 3(2), 199-244.

Hunt, K. W. (1965) Grammatical Structures Written as Three Grade Levels (NCTE Research Report Number 3). Urbana, IL: National Council of Teachers of English.

Jing, W. (2015) Theme and thematic progression in English writing teaching. Journal of Education and Practice, 6(21), 178-187.

Johnson-Cartee, K. S. (2005). News Narrative and News Framing: Constructing Political Reality. Lanham: MD, Rowman \& Littlefield.

Jones, R. H. and Lock, G. (2011) Functional Grammar in the ESL Classroom: Noticing, Exploring and Practising. Basingstoke: Palgrave Macmillan. 
Kadhim, K. A. and Shaker al-Shaibani, G. K. (2013) Analysis of thematic structure in English. Topics in Linguistics, 12, 33-45.

Kamler, B. and Thomson, P. (2006) Helping Doctoral Students Write. London and New York: Routledge.

Kerlil, A. (2005) Nash'at Assahafa fi el-jaza'ir [The emergence of the press in Algeria]. AlMasader, 11, 217-235.

Lock, G. (1996) Functional English Grammar: An Introduction for Second Language Teachers. Cambridge: Cambridge University Press.

McCabe, A. (1999) Theme and Thematic Patterns in Spanish and English History Text. (Doctoral thesis). Aston University, Aston, UK.

McCarthy, M. (1 991). Discourse Analysis for Language Teachers. Cambridge: Cambridge University Press.

Paltridge, B. (2006) Discourse Analysis: An Introduction. London: Continuum.

Prince, E. F. (1979) On the given/new distinction. In P. R. Clyne, W. F. H. \& Hofbauer, C. L. (Eds.), Papers from the fifteenth regional meeting of the Chicago Linguistics Society (pp. 257-278). Chicago: University of Chicago Press.

Prince, E. F. (1981) Toward a taxonomy of given-new information. In: Peter Cole (Ed.) Radical Pragmatics (pp.223-255). New York: Academic Press.

Quirk, R. et al. (1985) A Comprehensive Grammar of the English Language. London: Longman.

Saif Al Islam, Z. (1981). Ruad Essahafa El-jaza'iria [The pioneers of Algerian press]. Cairo: El-Shaab Prints House.

Saif Al Islam, Z. (1982) Tarikh Essahafa fi El-jazair [The history of the press in Algeria]. Algiers: SNED.

Schmidt, D. A. (1980) A History of Inversions in English. (Doctoral thesis). Ohio State University, Ohio, USA.

Sesan, A. A. (2013) Literature, Global Terrorism, Politics and Media Literacy in Africa. In: Khazar Journal of Humanities and Social Sciences, Vol. 16/4. (pp. 69-85). DOI: 10.5782/2223-2621.2013.16.4.69. Baku: Khazar University Press.

Sharndama, E.C. and Panamah, J. H. (2013) Thematic structure and progression in selected business news reports of two Nigerian newspapers: Implications for professional writing. Journal of Arts and Humanities, 2 (7), 72-81.

Thompson, G. (2014) Introducing Functional Grammar ( $3^{\text {rd }}$ ed.). London and New York: Routledge.

Thomson, E. A. (2005) Theme unit analysis: A Systemic-functional treatment of textual meanings in Japanese. Functions of Language, 12(2):151-179.

Thornbury, S. (2005) Beyond the Sentence: Introducing Discourse Analysis. London: Macmillan.

Trask, R.L. (2007) Language and Linguistics: The Key Concepts (2nd ed.). London: Routledge.

Van Dijk, T. A. (1985) Structures of news in the press. In: Teun A. Van Dijk (Ed.), Discourse and communication (pp. 69-93). Berlin: De Gruyter. 


\section{Appendix A: Echorouk Articles}

\begin{tabular}{|c|c|c|c|c|}
\hline $\mathbf{N}^{\circ}$ & Title & URL & $\begin{array}{c}\mathbf{N}^{\circ} \text { of } \\
\text { words }\end{array}$ & Date \\
\hline 1 & $\begin{array}{l}\text { Car price increases by } \\
1,000,000 \mathrm{DZ} \text { in Algeria }\end{array}$ & $\begin{array}{l}\text { https://www.echoroukonline.co } \\
\text { m/car-price-increases-by- } \\
\text { 1000000-dz-in-algeria/ }\end{array}$ & 167 & $\begin{array}{l}\text { June 24, } \\
2016\end{array}$ \\
\hline 2 & $\begin{array}{l}\text { Half A Million Algerians } \\
\text { Have Visited Tunisia Since } \\
\text { the Start Of 2016! }\end{array}$ & $\begin{array}{l}\text { https://www.echoroukonline.co } \\
\text { m/half-a-million-algerians- } \\
\text { have-visited-tunisia-since-the- } \\
\text { start-of-2016/ }\end{array}$ & 143 & $\begin{array}{l}\text { June 23, } \\
2016\end{array}$ \\
\hline 3 & $\begin{array}{l}\text { Taxation Represents } 1 / 3 \text { Of } \\
\text { the State's Budget }\end{array}$ & $\begin{array}{l}\text { https://www.echoroukonline.co } \\
\text { m/taxation-represents-1-3-of- } \\
\text { the-states-budget/ }\end{array}$ & 329 & $\begin{array}{l}\text { June } 20 \text {, } \\
2016\end{array}$ \\
\hline 4 & $\begin{array}{l}\text { Eni gains new contracts in } \\
\text { Algeria }\end{array}$ & $\begin{array}{l}\text { https://www.echoroukonline.co } \\
\text { m/eni-gains-new-contracts-in- } \\
\text { algeria/ }\end{array}$ & 153 & $\begin{array}{l}\text { June 23, } \\
2016\end{array}$ \\
\hline 5 & $\begin{array}{l}\text { Banking cards to buy and sell } \\
\text { available in Algeria within } 10 \\
\text { days }\end{array}$ & $\begin{array}{l}\text { https://www.echoroukonline.co } \\
\text { m/banking-cards-to-buy-and- } \\
\text { sell-available-in-algeria-within- } \\
\text { 10-days/ }\end{array}$ & 153 & $\begin{array}{l}\text { June 23, } \\
2016\end{array}$ \\
\hline 6 & $\begin{array}{l}\text { Air Algerie has } 260 \text { billion } \\
\text { centimes budget deficit }\end{array}$ & $\begin{array}{l}\text { https://www.echoroukonline.co } \\
\text { m/air-algerie-has-260-billion- } \\
\underline{\text { centimes-budget-deficit/ }}\end{array}$ & 114 & $\begin{array}{l}\text { June 20, } \\
2016\end{array}$ \\
\hline 7 & $\begin{array}{l}\text { Algeria freezes examination of } \\
\text { relative and anticipated } \\
\text { retirement applications }\end{array}$ & $\begin{array}{l}\text { https://www.echoroukonline.co } \\
\text { m/algeria-freezes-examination- } \\
\text { of-relative-and-anticipated- } \\
\text { retirement-applications/ }\end{array}$ & 199 & \\
\hline 8 & $\begin{array}{l}\text { Bouterfa: I will bring } \\
\text { Algeria's gas share in Europe }\end{array}$ & $\begin{array}{l}\text { https://www.echoroukonline.co } \\
\text { m/bouterfa-i-will-bring- } \\
\text { algerias-gas-share-in-europe/ }\end{array}$ & 178 & $\begin{array}{l}\text { June 14, } \\
2016\end{array}$ \\
\hline 9 & $\begin{array}{l}\text { BenKhalfa: "I just said the } \\
\text { truth" }\end{array}$ & $\begin{array}{l}\text { https://www.echoroukonline.co } \\
\text { m/benhalfa-i-just-said-the-truth/ }\end{array}$ & 151 & $\begin{array}{l}\text { June } 13, \\
2016\end{array}$ \\
\hline 10 & $\begin{array}{l}\text { Sonatrach, Sonelgaz and water } \\
\text { sector are exclusively } \\
\text { authorized to borrow money }\end{array}$ & $\begin{array}{l}\text { https://www.echoroukonline.co } \\
\text { m/sonatrach-sonelgaz-and- } \\
\text { water-sector-are-exclusively- } \\
\text { authorized-to-borrow-money/ }\end{array}$ & 199 & $\begin{array}{l}\text { June 13, } \\
2016\end{array}$ \\
\hline 11 & $\begin{array}{l}\text { Three international reports } \\
\text { excoriated Khebri } \\
\text { Benkhalfa }\end{array}$ & $\begin{array}{l}\text { https://www.echoroukonline.co } \\
\text { m/three-international-reports- } \\
\text { excoriated-khebri-and- } \\
\text { benkhalfa/ }\end{array}$ & 210 & $\begin{array}{l}\text { June } 12 \text {, } \\
2016\end{array}$ \\
\hline 12 & $\begin{array}{l}\text { Algeria Contributed to The } \\
\text { Entry Of Faiz Seradj To }\end{array}$ & $\begin{array}{l}\text { https://www.echoroukonline.co } \\
\text { m/algeria-contributed-to-the- }\end{array}$ & 366 & $\begin{array}{l}\text { June 11, } \\
2016\end{array}$ \\
\hline
\end{tabular}


Thematic Progression in Online Algerian Newspaper Articles:

\begin{tabular}{|c|c|c|c|c|}
\hline & Tripoli & entry-of-faiz-seradj-to-tripoli/ & & \\
\hline 13 & $\begin{array}{l}\text { Abderrahman Mebtoul: } \\
\text { "Government Should Choose } \\
\text { either Structural Reforms or } \\
\text { Resort to IMF" }\end{array}$ & $\begin{array}{l}\text { https://www.echoroukonline.co } \\
\text { m/abderrahman-mebtoul- } \\
\text { government-should-choose- } \\
\text { either-structural-reforms-or- } \\
\text { resort-to-imf/ }\end{array}$ & 144 & $\begin{array}{l}\text { June 11, } \\
2016\end{array}$ \\
\hline 14 & $\begin{array}{l}\text { Algeria's Ambassador to } \\
\text { Paris: your colonization } \\
\text { system is criminal and unjust }\end{array}$ & $\begin{array}{l}\text { https://www.echoroukonline.co } \\
\text { m/algerias-ambassador-to-paris- } \\
\text { your-colonization-system-is- } \\
\text { criminal-and-unjust/ }\end{array}$ & 389 & $\begin{array}{l}\text { June 10, } \\
2016\end{array}$ \\
\hline 15 & $\begin{array}{l}\text { Lawsuits raise panic among } \\
\text { ENSEJ loan beneficiaries }\end{array}$ & $\begin{array}{l}\text { https://www.echoroukonline.co } \\
\text { m/lawsuits-raise-panic-among- } \\
\text { ensej-loan-beneficiaries/ }\end{array}$ & 137 & $\begin{array}{l}\text { July 19, } \\
2016\end{array}$ \\
\hline
\end{tabular}

\section{Appendix B: Ennahar Articles}

\begin{tabular}{|c|c|c|c|c|}
\hline $\mathbf{N}^{\circ}$ & Title & URL & $\begin{array}{l}\mathbf{N}^{\circ} \text { of } \\
\text { words }\end{array}$ & Date \\
\hline 1 & $\begin{array}{l}\text { Army destroys } 2 \text { shelters for } \\
\text { terrorists in Batna, } 10 \text { mines in } \\
\text { Tizi Ouzou }\end{array}$ & $\begin{array}{l}\text { https://www.ennaharonline.com } \\
\text { /en/news/12584.html }\end{array}$ & 169 & $\begin{array}{l}\text { June } 24, \\
2016\end{array}$ \\
\hline 2 & $\begin{array}{l}\text { The pied noirs will not be } \\
\text { compensated for the property } \\
\text { they owned in Algeria }\end{array}$ & $\begin{array}{l}\text { www.ennaharonline.com/en/ne } \\
\text { ws/12583.html?print }\end{array}$ & 132 & $\begin{array}{l}\text { June } 22, \\
2016\end{array}$ \\
\hline 3 & $\begin{array}{l}\text { Intelligent } \text { solar house } \\
\text { prototype inaugurated in } \\
\text { Algiers }\end{array}$ & $\begin{array}{l}\text { www.ennaharonline.com/en/ne } \\
\text { ws/12583.html?print }\end{array}$ & 240 & $\begin{array}{l}\text { June } 22, \\
2016\end{array}$ \\
\hline 4 & $\begin{array}{l}\text { Hyundai's new facility in } \\
\text { Algeria starts production in } \\
\text { July }\end{array}$ & $\begin{array}{l}\text { www.ennaharonline.com/en/ne } \\
\text { ws/12580.html?print }\end{array}$ & 78 & $\begin{array}{l}\text { June } 22 \text {, } \\
2016\end{array}$ \\
\hline 5 & $\begin{array}{lr}\text { Algeria recovers } & \begin{array}{r}\text { French } \\
\text { diplomatic }\end{array} \\
\text { documents } \\
\text { covering the period } & 1954-1962\end{array}$ & $\begin{array}{l}\text { nline.com/en/ne } \\
\text { ?print }\end{array}$ & 192 & $\begin{array}{l}\text { June } 22, \\
2016\end{array}$ \\
\hline 6 & $\begin{array}{l}\text { A new cement plant project } \\
\text { begun in Bechar }\end{array}$ & $\begin{array}{l}\text { www.ennaharon } \\
\text { ws/12583.html?p }\end{array}$ & 176 & $\begin{array}{l}\text { June } 22, \\
2016\end{array}$ \\
\hline 7 & $\begin{array}{l}\text { Tunisia's STEG to get } 100 \\
\text { megawatts of electricity from } \\
\text { Algeria }\end{array}$ & $\begin{array}{l}\text { www.ennaharonline.com/en/ne } \\
\text { ws/12593.html?print }\end{array}$ & 128 & $\begin{array}{l}\text { June } 24, \\
2016\end{array}$ \\
\hline 8 & $\begin{array}{l}\text { DZD50 billion for a mining } \\
\text { railway project, entrusted to } \\
\text { public firms }\end{array}$ & $\begin{array}{l}\text { www.ennaharonline.com/en/ne } \\
\text { ws/12593.html?print }\end{array}$ & 159 & $\begin{array}{l}\text { July } 27, \\
2016\end{array}$ \\
\hline 9 & $\begin{array}{l}3 \quad \text { shelters for terrorists } \\
\text { destroyed in Boumerdes }\end{array}$ & $\begin{array}{l}\text { www.ennaharonline.com/en/ne } \\
\text { ws/12583.html?print }\end{array}$ & 123 & $\begin{array}{l}\text { June 22, } \\
2016\end{array}$ \\
\hline
\end{tabular}




\begin{tabular}{|c|c|c|c|c|}
\hline 10 & $\begin{array}{l}\text { Le Monde confirms what } \\
\text { Ennahar TV said } 3 \text { months ago } \\
\text { over Rebrab's corruption }\end{array}$ & $\begin{array}{l}\text { www.ennaharonline.com/en/ne } \\
\text { ws/12593.html?print }\end{array}$ & 175 & $\begin{array}{l}\text { July } 26, \\
2016\end{array}$ \\
\hline 11 & $\begin{array}{l}\text { Bedoui urges prefects to } \\
\text { launch high yield projects }\end{array}$ & $\begin{array}{l}\text { www.ennaharonline.com/en/ne } \\
\text { ws/12866.html?print }\end{array}$ & 100 & $\begin{array}{l}\text { July } 25, \\
2016\end{array}$ \\
\hline 12 & $\begin{array}{l}\text { The terrorist "M, Mouhamed" } \\
\text { surrendered himself }\end{array}$ & $\begin{array}{l}\text { www.ennaharonline.com/en/ne } \\
\text { ws/12866.html?print }\end{array}$ & 59 & $\begin{array}{l}\text { July } 25, \\
2016\end{array}$ \\
\hline 13 & $\begin{array}{l}\text { Algeria-U.S.: renewing } \\
\text { agreement in scientific and } \\
\text { technological fields Algeria- } \\
\text { U.S.: renewing agreement in } \\
\text { scientific and technological } \\
\text { fields }\end{array}$ & $\begin{array}{l}\text { www.ennaharonline.com/en/ne } \\
\text { ws/12858.html }\end{array}$ & 137 & $\begin{array}{l}\text { July } 25, \\
2016\end{array}$ \\
\hline 14 & $\begin{array}{l}\text { Algeria takes part in 21st } \\
\text { edition of "Global Village" in } \\
\text { Dubai }\end{array}$ & $\begin{array}{l}\text { www.ennaharonline.com/en/ne } \\
\text { ws/12858.html }\end{array}$ & 98 & $\begin{array}{l}\text { July } 25, \\
2016\end{array}$ \\
\hline 15 & $\begin{array}{l}\text { President } \text { Bouteflika appoints } \\
3 \text { new members of } \\
\text { Constitutional Council }\end{array}$ & $\begin{array}{l}\text { https://www.ennaharonline.com } \\
\text { /en/news/12877.html?print }\end{array}$ & 123 & $\begin{array}{l}\text { July } 27, \\
2016\end{array}$ \\
\hline
\end{tabular}

